\title{
Probiotic powder: Optimization of the process parameters and influence of the
}

\section{drying method}

\author{
Probiótico em Pó: otimização dos parâmetros de processamento e influência do método de secagem \\ Probiótico en polvo: Optimización de los parámetros del proceso e influencia del método de secado
}

Received: 11/23/2021 | Reviewed: 12/02/2021 | Accept: 12/06/2021| Published: 12/16/2021

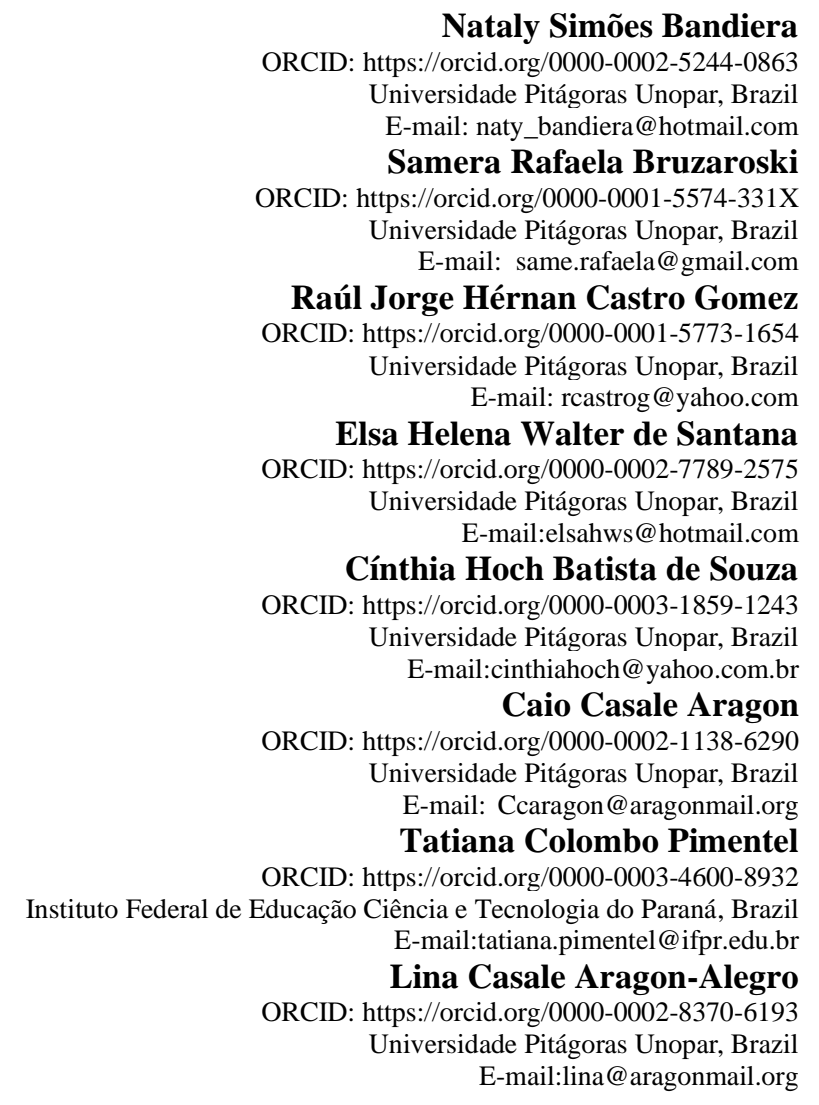

\begin{abstract}
This research paper aimed to optimize the process parameters and to select the most suitable drying method in order to obtain probiotic powder at reduced cost. The influence of the addition of growth promoters (glucose, sucrose, cheese whey, peptone, yeast extract or ammonium sulfate), incubation parameters (time and temperature) and drying method (freeze-drying or oven-drying) on the viability of the probiotic cultures Lactobacillus casei or Lactobacillus acidophilus was evaluated. The effect of the growth promoters was evaluated using a fractional factorial experimental design $2^{6-4}$ and the concentration of the growth promoters and the incubation temperature were optimized through Box-Behnken experimental matrix $\left(3^{3}\right)$. Cheese whey $(16 \% \mathrm{w} / \mathrm{v})$ plus ammonium sulfate $(2.5 \% \mathrm{w} / \mathrm{v})$ and cheese whey $(12 \% \mathrm{w} / \mathrm{v})$ plus yeast extract $(7 \% \mathrm{w} / \mathrm{v})$ promoted a higher multiplication of $L$. casei and L. acidophilus, respectively. The best temperature for L. casei was $35^{\circ} \mathrm{C}$ and for L. acidophilus $39^{\circ} \mathrm{C}$, without influence of the incubation time $(24$ or $48 \mathrm{~h}$ ). The oven-drying resulted in the highest populations of the probiotic cultures (above $9 \log \mathrm{cfu} / \mathrm{mL}$ ). This study proved that cheese whey can be a suitable growth promoter for both probiotic cultures and oven-drying could be the drying method, which can decrease the production costs. The influence of the temperature and growth promoters is strain specific, demonstrating that the growth conditions should be evaluated for each probiotic strain.
\end{abstract}

Keywords: Lactobacillus casei; Lactobacillus acidophilus; Cheese whey; Freeze-drying; Oven-drying.

\section{Resumo}

O objetivo foi otimizar os parâmetros de processamento e definir o melhor método de secagem para a obtenção de um pó probiótico de baixo custo. Avaliaou-se a influência da adição de promotores de crescimento (glicose, sacarose, soro de queijo, peptona, extrato de levedura ou sulfato de amônio), dos parâmetros de incubação (tempo e 
temperatura) e dos método de secagem (liofilização ou secagem em estufa) sobre a viabilidade das culturas probióticas Lactobacillus casei e Lactobacillus acidophilus. O efeito dos promotores de crescimento foi avaliado utilizando-se um delineamento experimental fatorial fracionado (padrão de $2^{6-4} ; 2$ ) e a concentração dos promotores de crescimento e a temperatura de incubação foram otimizadas através da matriz experimental Box-Behnken $\left(3^{3}\right)$. Soro de queijo $(16 \% \mathrm{c} / \mathrm{v})$ mais sulfato de amônio $(2,5 \% \mathrm{w} / \mathrm{v})$ e soro de queijo $(12 \% \mathrm{w} / \mathrm{v})$ mais extrato de levedura $(7 \%$ c/v) promoveram uma maior multiplicação de $L$. casei e L. acidphilus, respectivamente. A melhor temperatura para $L$. casei foi de $35^{\circ} \mathrm{C}$ e para L. acidphilus, $39^{\circ} \mathrm{C}$, sem influência do tempo de incubação (24 ou $48 \mathrm{~h}$ ). A secagem em estufa resultou nas maiores populações das culturas (acima de $9 \log \mathrm{cfu} / \mathrm{mL}$ ). Este estudo comprovou que o soro de queijo pode ser um bom promotor de crescimento para as culturas probióticas utilizadas e que a secagem em forno pode ser utilizada, reduzindo os custos de produção. A influência da temperatura e dos promotores de crescimento é específica para cada espécie, demonstrando que as condições de crescimento devem ser avaliadas para cada cepa probiótica.

Palavras-chave: Lactobacillus casei; Lactobacillus acidophilus; Soro de queijo; Liofilização; Secagem em estufa.

\section{Resumen}

El objetivo fue optimizar los parámetros de procesamiento y definir el mejor método de secado para obtener un polvo probiótico de bajo costo. Se evaluó la influencia de la adición de promotores del crecimiento (glucosa, sacarosa, suero de queso, peptona, extracto de levadura o sulfato de amonio), parámetros de incubación (tiempo y temperatura) y métodos de secado (liofilización o secado en invernadero) sobre la viabilidad de los cultivos probióticos Lactobacillus casei y Lactobacillus acidophilus. El efecto de los promotores de crecimiento se evaluó mediante un diseño experimental factorial fraccional (estándar de 26-4; 2) y la concentración de promotores de crecimiento y la temperatura de incubación se optimizaron utilizando la matriz experimental Box-Behnken (33). El suero de queso $(16 \% \mathrm{p} / \mathrm{v})$ más sulfato de amonio $(2,5 \% \mathrm{p} / \mathrm{v})$ y suero de queso $(12 \% \mathrm{p} / \mathrm{v})$ más extracto de levadura $(7 \% \mathrm{p} / \mathrm{v})$ promovieron una mayor multiplicación de $L$. casei y L. acidophilus, respectivamente. La mejor temperatura para $L$. casei fue de $35^{\circ} \mathrm{C}$ y para L. acidpohilus, de $39^{\circ} \mathrm{C}$, sin influencia del tiempo de incubación (24 o $\left.48 \mathrm{~h}\right)$. El secado en horno resultó en las poblaciones de cultivos más grandes (por encima de $9 \log$ ufc / ml). Este estudio demostró que el suero de queso puede ser un buen promotor del crecimiento para los cultivos probióticos utilizados y que se puede utilizar el secado al horno, reduciendo los costos de producción. La influencia de la temperatura y los promotores del crecimiento es específica para cada especie, lo que demuestra que las condiciones de crecimiento deben evaluarse para cada cepa probiótica.

Palabras clave: Lactobacillus casei; Lactobacillus acidophilus; Suero de queso; Liofilización; Secado en horno.

\section{Introduction}

Probiotics are living microorganisms that confer beneficial effects on individuals when administered in adequate quantities $\left(10^{6}-10^{7}\right.$ cfu per gram or milliliter) (Hill, et al., 2014; Shu, et al., 2018). The large-scale production of probiotic products resulted in a demand for probiotic bacteria at low cost. Therefore, the development of rich medium and the determination of the most suitable incubation conditions are key environmental parameters required for the probiotic growth. Increased probiotic biomass facilitates the recovery process and reduces the production cost (Manzoor, et al., 2017).

Nutrient supplements, such as glucose, sucrose, yeast extract and peptone can improve the probiotic growth as they are source of organic nitrogen and carbonaceous compounds. Furthermore, inorganic compounds, such as $\left(\mathrm{NH}_{4}\right)_{2} \mathrm{SO}_{4}$ and $\left(\mathrm{NH}_{4}\right)_{2} \mathrm{HPO}_{4}$ could also increase the probiotic viability. However, their use in large quantities is expensive (Manzoor, et al., 2017; Pato, et al., 2017). Cheese whey is the main by-product of the cheese industry, has high nutritional value, functional properties, and economic importance. The presence of lactose, vitamins, minerals, and proteins makes cheese whey an interesting medium for probiotic bacteria growth (Sabo, et al., 2017). Therefore, designing new medium for increased biomass production can lead to probiotic production at lower cost. Lactic acid bacteria are strain-dependent fastidious bacteria with respect to nutrients and environmental requirements. Studies with agroindustry by-products as growth promoters are scarce as well as the evaluation of the strain specific requirements (Manzoor, et al., 2017).

Drying techniques are common technologies used for the long-term preservation of probiotic bacteria, such as freezedrying, spray-drying, vacuum-drying, oven-drying and fluidized bed-drying (Flach, et al., 2017; Shu, et al., 2018). The preparation of probiotic cultures in a powder form has some advantages, such as: increased convenience and practice 
(broadening the range of food applications), lower transportation costs, possibility of storage at ambient temperature, and higher dosage control (Alves, et al., 2017; Librán, et al., 2017).

Freeze-drying is considered the best method of water removal, resulting in final products with higher quality, such as good solubility, lower weight, and long shelf life (Tabassum, et al., 2017). However, this process results in loss of bacterial viability due to ice crystal formation and rupture of the cell membrane during the frozen step (Shu et al., 2018). Furthermore, it is relatively expensive (Librán, et al., 2017). The oven-drying technology is considered suitable because of the lower cost when compared to freeze-drying, however, thermal stress and dehydration are believed to negatively impact the probiotic viability (Flach, et al., 2017).

The incorporation of cheap and easily available raw materials and the use of efficient technologies are tightly related to the cost-effectiveness of the probiotic production (Kareb \& Aider, 2018). Therefore, the objectives of this study were: (1) to study the best growth promoters (glucose, sucrose, cheese whey, peptone, yeast extract or ammonium sulfate) to improve probiotic bacteria (Lactobacillus casei and L. acidophilus) viability, (2) to optimize the concentration of the selected components and the incubation parameters (temperature and time); and 3) to study the best drying method to obtain a powdered probiotic culture.

\section{Methodology}

Cheese whey (Confepar, Londrina, Brazil), glucose (Synth, Diadema-SP, Brazil), sucrose (Sigma-Aldrich, St. Louis, USA), peptone (Himedia, Mumbai, India), yeast extract (Himedia, Mumbai, India), ammonium sulfate (Química Moderna, Barueri, Brazil), plate count agar (PCA, Himedia, Mumbai, India), Man, Rogosa and Sharp agar (MRS, Himedia, Mumbai, India) and MRS broth (Himedia, Mumbai, India) were used in the experiment. Probiotic cultures (Lactobacillus casei and Lactobacillus acidophilus), both in a lyophilized form and stored at $-18^{\circ} \mathrm{C}$, were purchased from Christian Hansen (Valinhos, Brazil).

\subsection{Inoculum preparation}

The lyophilized probiotic cultures (L. casei and L. acidophilus) were separately activated in $20 \mathrm{~mL}$ of sterilized MRS broth and incubated at $37^{\circ} \mathrm{C}$ for $24 \mathrm{~h}$. After this period, $10 \%$ (w/v) of the medium were transferred to a flask containing $40 \mathrm{~mL}$ of MRS broth and incubated for $24 \mathrm{~h}$ at $37{ }^{\circ} \mathrm{C}$. Thereafter, the medium was centrifuged at $559 \mathrm{~g}$ for $5 \mathrm{~min}$ and the precipitate was washed with $40 \mathrm{~mL}$ of $0.85 \mathrm{~g} / 100 \mathrm{~g}$ sterile saline solution. The biomass was resuspended in $40 \mathrm{~mL}$ of the sterile 0.85 $\mathrm{g} / 100 \mathrm{~g}$ saline solution, constituting the activated probiotic culture.

\subsection{Evaluation of the growth promoters}

In order to define the growth promoters to be used for the cultivation of the probiotic cultures, the effects of the compounds on the multiplication of $L$. casei or L. acidophilus were evaluated. A fractional factorial experimental design $2^{6-4}$ with 6 independent factors and 16 experiments was used. Table 1 shows the six independent nutrient variables (glucose, sucrose, cheese whey, peptone, yeast extract and ammonium sulfate) with the respective design levels $(-1$ or +1$)$. Table 2 presents the 16 experiments, which were conducted separately for $L$. casei and L. acidophilus. 
Table 1. Real and coded values of the variables used in the fractional factorial experimental design.

\begin{tabular}{ccc}
\hline Variables $(\mathrm{g} / 100 \mathrm{~g})$ & \multicolumn{2}{c}{ Levels } \\
\cline { 2 - 3 } & -1 & +1 \\
\hline Glucose $\left(\mathrm{X}_{1}\right)$ & 0.7 & 7 \\
Sucrose $\left(\mathrm{X}_{2}\right)$ & 0.7 & 10 \\
Whey cheese $\left(\mathrm{X}_{3}\right)$ & 1 & 2 \\
Peptone $\left(\mathrm{X}_{4}\right)$ & 0.2 & 2 \\
Yeast extract $\left(\mathrm{X}_{5}\right)$ & 0.2 & 1 \\
Ammonium sulfate $\left(\mathrm{X}_{6}\right)$ & 0.01 & \\
\hline
\end{tabular}

Source: Authors.

For each experiment, the growth promoters were added in $20 \mathrm{~mL}$ of distilled water and in the concentrations previously defined (Table 1 and Table 2). The medium was sterilized $\left(121^{\circ} \mathrm{C} / 15 \mathrm{~min}\right.$ ), inoculated with the activated probiotic culture and incubated at $37^{\circ} \mathrm{C}$ for $24 \mathrm{~h}$. The populations of L. casei or L. acidophilus were determined in PCA after incubation at $37^{\circ} \mathrm{C}$ for $72 \mathrm{~h}$ and expressed in Colony Forming Units (cfu) $/ \mathrm{mL}$.

Table 2. Fractional factorial experimental design $2^{6-4}$ (6 independent factors and 16 experiments) and probiotic viability.

\begin{tabular}{|c|c|c|c|c|c|c|c|c|}
\hline Experiment & $\begin{array}{c}\text { Glucose } \\
\left(\mathrm{X}_{1}\right)\end{array}$ & $\begin{array}{c}\text { Sucrose } \\
\left(\mathrm{X}_{2}\right)\end{array}$ & $\begin{array}{c}\text { Whey } \\
\text { cheese } \\
\left(\mathrm{X}_{3}\right)\end{array}$ & $\begin{array}{c}\text { Yeast } \\
\text { extract } \\
\left(\mathrm{X}_{4}\right)\end{array}$ & $\begin{array}{c}\text { Peptone } \\
\left(\mathrm{X}_{5}\right)\end{array}$ & $\begin{array}{l}\text { Ammonium } \\
\text { sulfate } \\
\left(\mathrm{X}_{6}\right)\end{array}$ & L. acidophilus & L. casei counts \\
\hline 1 & -1 & -1 & -1 & -1 & -1 & -1 & 8.74 & 8.2 \\
\hline 2 & +1 & -1 & -1 & -1 & +1 & -1 & 8.66 & 8.36 \\
\hline 3 & -1 & +1 & +1 & -1 & -1 & +1 & 8.92 & 8.32 \\
\hline 4 & +1 & +1 & -1 & -1 & -1 & +1 & 9.3 & 8.2 \\
\hline 5 & -1 & -1 & +1 & -1 & +1 & +1 & 9.15 & 9.28 \\
\hline 6 & +1 & -1 & +1 & -1 & -1 & +1 & 6.3 & 9.11 \\
\hline 7 & -1 & +1 & +1 & -1 & -1 & -1 & 8.86 & 9.32 \\
\hline 8 & +1 & +1 & +1 & -1 & +1 & -1 & 7.6 & 9.26 \\
\hline 9 & -1 & -1 & -1 & +1 & -1 & +1 & 6.9 & 8.63 \\
\hline 10 & +1 & -1 & -1 & +1 & +1 & +1 & 7.11 & 8.36 \\
\hline 11 & -1 & +1 & -1 & +1 & +1 & -1 & 7.00 & 8.9 \\
\hline 12 & +1 & +1 & -1 & +1 & -1 & -1 & 7.00 & 8.49 \\
\hline 13 & +1 & +1 & -1 & -1 & -1 & +1 & 9.38 & 9.18 \\
\hline 14 & +1 & -1 & +1 & +1 & -1 & -1 & 9.20 & 9.23 \\
\hline 15 & -1 & +1 & +1 & +1 & -1 & +1 & 9.11 & 9.18 \\
\hline 16 & +1 & +1 & +1 & +1 & +1 & +1 & 8.93 & 9.15 \\
\hline
\end{tabular}

*L. acidophilus and L. casei in $\log$ cfu/mL. Source: Authors.

\subsection{Optimization of the growth promoter's concentration and incubation parameters}

After selecting the most suitable growth promoters for each probiotic strain (L. casei or L. acidophilus), their concentrations were optimized. In addition, the incubation temperature was also evaluated. The experiments were performed using the Box-Behnken $\left(3^{3}\right)$ experimental matrix, with 3 independent variables (cheese whey, yeast extract or ammonium sulfate and temperature) in 3 levels, totaling 15 experiments and 3 repetitions at the central point. Table 3 shows the three 
independent variables (whey cheese, yeast extract or ammonium sulfate and temperature) with the respective design levels (-1, 0 or +1 ) for L. acidophilus and L. casei. Table 4 presents the 15 experiments.

For each experiment, the selected growth promoters were added in $20 \mathrm{~mL}$ of distilled water and in the concentrations previously defined (Table 3$)$. The medium was sterilized $\left(121^{\circ} \mathrm{C} / 15 \mathrm{~min}\right)$, inoculated with the activated probiotic culture and incubated at $37^{\circ} \mathrm{C}$ for $24 \mathrm{~h}$. The populations of L. casei or L. acidophilus were determined in PCA agar after incubation at 37 ${ }^{\circ} \mathrm{C}$ for $72 \mathrm{~h}$ and expressed in $\mathrm{cfu} / \mathrm{mL}$.

To evaluate the effect of the incubation time, an experiment with the optimum growth promoters and in the optimum temperature was conducted using incubation times of 24 and $48 \mathrm{~h}$. After these periods, the microorganisms were enumerated in PCA and MRS agar by incubating at $37^{\circ} \mathrm{C}$ for $72 \mathrm{~h}$ in triplicate and the results were expressed in cfu/mL.

Table 3. Experimental levels used to optimize the concentration of the growth parameters for L. acidophilus and L. casei production.

\begin{tabular}{ccccc}
\hline Probiotic culture & Variables & $\mathbf{- 1}$ & $\mathbf{0}$ & $\mathbf{+ 1}$ \\
\hline L. acidophilus & Whey cheese $\left(\mathrm{Y}_{1}, \mathrm{~g} / 100 \mathrm{~mL}\right)$ & 6.0 & 11.0 & 16.0 \\
& Yeast extract $\left(\mathrm{Y}_{2}, \mathrm{~g} / 100 \mathrm{~mL}\right)$ & 3.0 & 7.0 & 11.0 \\
& Temperature $\left(\mathrm{Y}_{3},{ }^{\circ} \mathrm{C}\right)$ & 30 & 35 & 40 \\
L. casei & Whey cheese $\left(\mathrm{Y}_{1}, \mathrm{~g} / 100 \mathrm{~mL}\right)$ & 6.0 & 11.0 & 16.0 \\
& Ammonium sulfate $\left(\mathrm{Y}_{2}, \mathrm{~g} / 100 \mathrm{~mL}\right)$ & 0.5 & 2.5 & 4.5 \\
& Temperature $\left(\mathrm{Y}_{3},{ }^{\circ} \mathrm{C}\right)$ & 30 & 35 & 40 \\
\hline
\end{tabular}

Source: Authors.

Table 4. Box-Behnken experimental matrix with 3 independent variables and 15 experiments for $L$. acidophilus and $L$. casei

\begin{tabular}{|c|c|c|c|c|c|}
\hline Experiments & $\begin{array}{l}\text { Whey cheese } \\
\qquad\left(\mathrm{Y}_{1)}\right.\end{array}$ & $\begin{array}{c}\text { Yeast extract or Ammonium } \\
\text { sulfate } \\
\left(\mathrm{Y}_{2}\right) \\
\end{array}$ & Temperature $\left(\mathrm{Y}_{3}\right)$ & L. acidophilus & L. casei \\
\hline 1 & -1 & -1 & 0 & 8.34 & 9.29 \\
\hline 2 & +1 & -1 & 0 & 8.89 & 9.70 \\
\hline 3 & -1 & +1 & 0 & 8.56 & 9.04 \\
\hline 4 & +1 & +1 & 0 & 8.71 & 9.62 \\
\hline 5 & -1 & 0 & -1 & 8.08 & 9.15 \\
\hline 6 & +1 & 0 & -1 & 7.96 & 9.66 \\
\hline 7 & -1 & 0 & +1 & 8.69 & 8.57 \\
\hline 8 & +1 & 0 & +1 & 8.96 & 9.42 \\
\hline 9 & 0 & -1 & -1 & 8.11 & 8.79 \\
\hline 10 & 0 & +1 & -1 & 8.04 & 9.60 \\
\hline 11 & 0 & -1 & +1 & 8.98 & 9.09 \\
\hline 12 & 0 & +1 & +1 & 8.98 & 8.79 \\
\hline 13 & 0 & 0 & 0 & 9.02 & 9.57 \\
\hline 14 & 0 & 0 & 0 & 8.72 & 9.58 \\
\hline 15 & 0 & 0 & 0 & 8.91 & 9.56 \\
\hline
\end{tabular}

*L. acidophilus and L. casei in $\log \mathrm{cfu} / \mathrm{mL}$;** Yeast extract for L. acidophilus and ammonium sulfate for L. casei. Source: Authors.

\subsection{Effect of the drying technology}

The media with the most suitable characteristics was submitted to two drying technologies: oven-drying at $40{ }^{\circ} \mathrm{C}$ for $24 \mathrm{~h}$ or freeze-drying at $-45^{\circ} \mathrm{C}$ for $24 \mathrm{~h}$. After this period, the obtained products were ground, and the probiotic cultures were enumerated in PCA and MRS agar after incubation at $37^{\circ} \mathrm{C}$ for $72 \mathrm{~h}$, in triplicate. The results were expressed in cfu/mL.

\subsection{Statistical analysis}

The Statistica software 7.0 was used for experimental design, regression analysis, response surface graphs and process optimization. The effects of the variables on probiotic viability were statistically analyzed with analysis of variance (ANOVA) and Tukey test $(\mathrm{p}=0.05)$. The fitting quality of the model equation was checked using the determination coefficient $\left(\mathrm{R}^{2}\right)$. The 
optimized process parameters were obtained by the numerical optimization method considering the experimental range (Manzoor, et al., 2017; Thakur, et al., 2018).

\section{Results and Discussion}

\subsection{Selection of the growth promoters}

Table 2 presents the viability of the probiotic cultures in the 16 experiments of the fractional factorial experimental design $2^{6-4}$. The highest population of L. acidophilus was observed in the experiments 4 and 13, with higher concentrations of glucose, sucrose and ammonium sulfate, and lower concentrations of cheese whey, yeast extract and peptone $(9.30 \log \mathrm{cfu} / \mathrm{mL}$ and $9.38 \log \mathrm{cfu} / \mathrm{mL}$, respectively). For $L$. casei, the highest population was observed in the experiments 5 , with higher concentrations of cheese whey, peptone and ammonium sulfate, and lower concentrations of glucose, sucrose and yeas extract (9.28 $\log \mathrm{cfu} / \mathrm{mL})$ and 7, with higher concentrations of sucrose and cheese whey, and lower concentrations of the other subtracts $(9.32 \log \mathrm{cfu} / \mathrm{mL})$.

Equation 1 represents the coded mathematical model for the $L$. casei viability as a function of the growth promoters that presented statistical significance $(\mathrm{p}<0.05)$. The coefficients of the equation were obtained using the regression coefficients.

$$
\text { L. casei }(\log \mathrm{cfu} / \mathrm{mL})=8.83+0.13 \mathrm{X}_{3}
$$

The results indicate that the cheese whey $\left(\mathrm{X}_{3}\right)$ was the only growth promoter that had significant $(\mathrm{p}=0.0018)$ and positive impact on the viability of $L$. casei. Therefore, on the studied range $(1-10 \mathrm{~g} / 100 \mathrm{~g})$, an increase in the whey cheese concentration in the medium resulted in an increase in the L. casei counts. The presence of lactose, vitamins, minerals, and proteins in the cheese whey could be related to the increased probiotic growth (Sabo, et al., 2017).

In relation to the other growth promoters (glucose, sucrose, yeast extract, peptone and ammonium sulfate), it was observed that these components had no impact $(\mathrm{p}>0.05)$ on the $L$. casei viability. It should be noted, however, that the interaction of cheese whey with ammonium sulfate was the only interaction that presented a positive effect $(+0.021)$, although not significant $(\mathrm{p}=0.792767)$. Therefore, the cheese whey and the ammonium sulfate were selected as the best growth promoters to constitute the culture medium used for the multiplication of $L$. casei. The utilization of cheese whey and ammonium sulfate as growth promoters is interesting, as these components are considered of low-cost. Furthermore, the extensive use of nitrogenous sources, as peptones and yeast extract, is considered environment unfriendly because of the quantity of waste (Manzoor, et al., 2017). Equation 2 represents the coded mathematical model for the L. acidophilus viability as a function of the growth promoters that presented statistical significance $(p<0.05)$. The coefficients of the equation were obtained using the regression coefficients.

$$
\text { L. acidophilus }(\log \mathrm{cfu} / \mathrm{mL})=8.26+1.54 \mathrm{X}_{3} \mathrm{X}_{4}
$$

The results indicate that the cheese whey $\left(\mathrm{X}_{3}\right)$ and yeast extract $\left(\mathrm{X}_{4}\right)$ interaction had significant $(\mathrm{p}=0.013)$ and positive impact on the viability of L. acidophilus. Therefore, on the studied range, an increase in the whey cheese and yeast extract concentrations in the medium resulted in an increase in the L. acidophilus counts. Therefore, the cheese whey and the yeast extract were selected as the best growth promoters to constitute the culture medium used for the multiplication of $L$. acidophilus. 
The cheese whey was a suitable component to improve the growth of both probiotic cultures evaluated in the present study (L. acidophilus and L. casei). The cost of the culture medium has a remarkable impact on the mass production of probiotics, therefore, the substitution of traditional nutrients by low-price nutrient ingredients, such as the cheese whey, are vital for the economical probiotic production (Manzoo,r et al., 2017). Cheese whey is a by-product of the cheese industry and is a potential pollutant. When using $10 \mathrm{~L}$ of milk for cheese production, it is possible to obtain $1-2 \mathrm{~kg}$ of cheese and 8-9 $\mathrm{L}$ of whey are generated, with estimated worldwide cheese whey production of 160 million tons per year. From this amount, only $30-50 \%$ are utilized (Kareb \& Aider, 2018).

The results indicate that the probiotic cultures have different nutrition requirements, as for L. casei only cheese whey had a positive impact, while for L. acidophilus both yeast extract and cheese whey were important. Probiotic viability is dependent on the composition of the medium. Yeast extract is a nitrogen, carbon and vitamin source and metal ions, such as ammonium sulfate, can also improve the probiotic viability (Manzoor, et al., 2017). In fact, L. acidophilus has specific nutritional requirements, with need of amino acids (Glu and Gly), vitamins (pyridoxine and nicotinamide), ions $\left(\mathrm{K}^{+}\right.$and $\mathrm{PO}_{4}{ }^{3-}$ ), and purines and pyrimidines (guanine and uracil) (Lv, et al., 2017). On the other hand, L. casei does not have a high nutritional requirement, as the presence of many amino acid did not impact on this strain viability (Zotta, et al., 2017). Therefore, a richer medium is necessary for improving the L. acidophilus viability.

\subsection{Optimization of the concentration of the growth promoters and incubation parameters}

Table 4 presents the L. casei and L. acidophilus viabilities in the 15 experiments for the optimization of the concentration of the growth promoters and incubation parameters. Equation 3 represents the coded mathematical model for the L. casei viability as a function of the variables that presented statistical significance $(\mathrm{p}<0.05)$. The coefficients of the equation were obtained using the regression coefficients. The lack of fit of the model was non-significant, demonstrating good correlation between the data and the model. The high $\mathrm{R}^{2}$ value $(0.94)$ indicated that the data were close to the predicted values from the model.

L. casei $(\log \mathrm{cfu} / \mathrm{mL})=9.22+0.59 \mathrm{Y}_{1}-0.33 \mathrm{Y}_{3}+0.36 \mathrm{Y}_{3}^{2}-0.55 \mathrm{Y}_{2} \mathrm{Y}_{3}$ (Eq. 3)

The results indicate that the cheese whey $\left(\mathrm{Y}_{1}\right)$ had an important and significant positive effect on the $L$. casei counts ( $\mathrm{p}=0.002897)$. Therefore, increasing the concentration of cheese whey from $6 \mathrm{~g} / 100 \mathrm{~mL}$ to $16 \mathrm{~g} / 100 \mathrm{~mL}$ resulted in increases in the $L$. case i counts. The temperature had a negative linear $(\mathrm{p}=0.027)$ and a positive quadratic $(\mathrm{p}=0.006)$ influence on the L. casei counts. Therefore, higher temperatures can be responsible for decreasing the L. casei counts.

Figure 1A shows the effect of temperature and cheese whey concentration on the L. casei counts when the concentration of ammonium sulfate was $2.5 \mathrm{~g} / 100 \mathrm{~mL}$ (non-significant variable, $\mathrm{p}>0.05$ ). It can be observed that the highest population of this probiotic culture occur in concentrations of cheese whey between 14 and $16 \%$ and incubation temperature between 31 and $37{ }^{\circ} \mathrm{C}$. An optimized formulation was suggested from the software at the following conditions: $16 \%$ of whey $(\mathrm{w} / \mathrm{v}), 2.5 \%$ of ammonium sulfate (w/v) and incubation temperature of $35^{\circ} \mathrm{C}$.

Equation 4 represents the coded mathematical model for the L. acidophilus viability as a function of variables that presented statistical significance $(\mathrm{p}<0.05)$. The coefficients of the equation were obtained using the regression coefficients. The lack of fit of the model was non-significant, demonstrating good correlation between the data and the model. The high $\mathrm{R}^{2}$ value (0.96) indicated that the data were close to the predicted values from the model.

L. acidophilus $(\log \mathrm{cfu} / \mathrm{mL})=8.53+0.86 \mathrm{Y}_{3}+0.18 \mathrm{Y}_{1}^{2}+0.28 \mathrm{Y}_{3}^{2}$ (Eq. 4) 
The results indicate that the cheese whey $\left(\mathrm{Y}_{1}\right)$ had an important and significant positive quadratic effect on the $L$. acidophilus counts $(\mathrm{p}=0.048)$. The temperature had a positive linear $(\mathrm{p}=0.000284)$ and a positive quadratic $(\mathrm{p}=0.01)$ influence on the L. acidophilus counts. Therefore, higher temperatures can be responsible for increases in the L. acidophilus counts.

Figure 1B shows the effect of temperature and cheese whey concentration on the L. acidophilus counts when the concentration of yeast extract was $7 \mathrm{~g} / 100 \mathrm{~mL}$ (non-significant variable, $\mathrm{p}>0.05$ ). The highest population of this probiotic culture occur in concentrations of cheese whey between 9 and $16 \%$ and incubation temperature between 36.5 and $40{ }^{\circ} \mathrm{C}$. An optimized formulation was suggested from the software at the following conditions: $12 \%$ of cheese whey (w/v), $7 \%$ of yeast extract (w/v) and incubation temperature of $39{ }^{\circ} \mathrm{C}$.

Figure 1. Effect of cheese whey concentration and incubation temperature on L. casei (A) or L. acidophilus (B) viabilities (log $\mathrm{cfu} / \mathrm{mL})$.
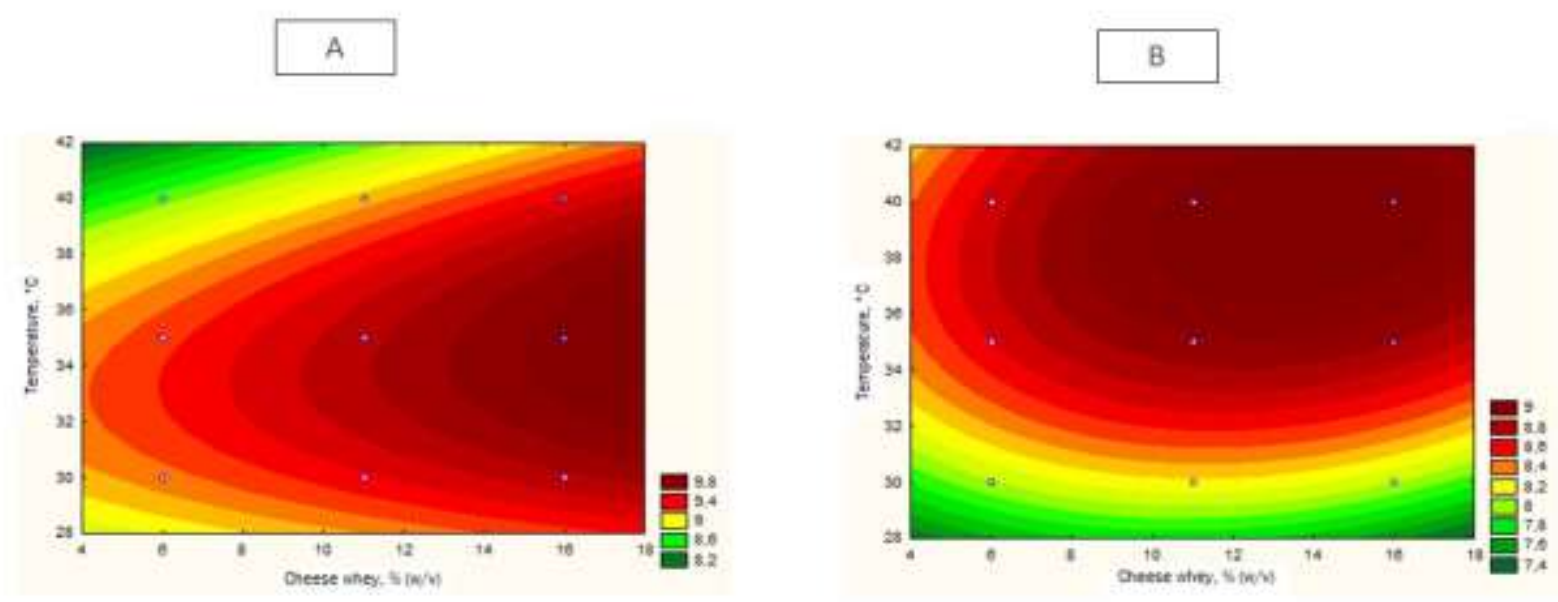

Source: Authors.

The results indicate that the probiotic cultures have different optimum incubation temperature, as for $L$. casei it was $35^{\circ} \mathrm{C}$, while for L. acidophilus it was $39^{\circ} \mathrm{C}$. This is an interesting result, as it establishes the optimum temperature to be used, resulting in higher concentrations of the probiotic culture and, consequently, with probable reduction of the probiotic costs. In fact, probiotic cultures can be thermophilic or mesophilic with optimum temperatures between 30 and $44^{\circ} \mathrm{C}$. For $\mathrm{L}$. casei, the probiotic viability tends to reduce at higher temperatures than the optimum temperature and the optimum temperature was defined as close to $37^{\circ} \mathrm{C}$ (Thakur, et al., 2018). On the contrary, L. acidophilus viability seems to increase when the temperature increases $\left(30\right.$ to $45^{\circ} \mathrm{C}$ ), with the optimum temperature close to $37^{\circ} \mathrm{C}$ (Bevilacqua, et al., 2017). The optimum temperature should be evaluated in each case, as it is dependent on the other conditions of the medium, such as the chemical composition (Bevilacqua, et al., 2017; Thakur, et al., 2018).

\subsection{Definition of the incubation time}

The probiotic viability after 24 and $48 \mathrm{~h}$ of incubation are shown in Table 5 . The incubation time $(24$ or $48 \mathrm{~h})$ of $L$. casei and L. acidophilus in the optimum condition of medium composition and temperature did not present significant 
difference in the probiotic viability $(\mathrm{p}>0.05)$. Therefore, it is recommended to use the lowest incubation time $(24 \mathrm{~h})$, aiming cost reduction. Incubation times higher than $12 \mathrm{~h}$ are recommended, because the probiotic strains present higher growth profiles and can reach the stationary phase ( $\mathrm{Hu}$, et al., 2018). Incubation times of 15-48 h are usually used, but the optimum time should be evaluated (Guergoletto, et al., 2010), mainly in the optimum temperature.

The probiotic cultures were incubated in PCA and MRS agar, and no significant differences were observed in the probiotic counts in both agars ( $>$ > 0.05). The MRS and M17 media are known to be the most appropriate for the growth and isolation of lactic acid bacteria (Ayodeji, et al., 2017). This is an interesting result, since the PCA agar has lower cost than the MRS agar (Sigma-Aldrich, 2021).

Table 5. Probiotic viability in different incubation times.

\begin{tabular}{ccc}
\hline Incubation parameters & $\begin{array}{c}\text { L. casei } \\
(\log \mathrm{cfu} / \mathrm{mL})\end{array}$ & $\begin{array}{c}\text { L. acidophilus } \\
(\operatorname{log~cfu} / \mathrm{mL})\end{array}$ \\
\hline PCA / 24 h & $9.46 \pm 0.53^{\mathrm{a}}$ & $8.95 \pm 0.47^{\mathrm{a}}$ \\
PCA / 48 h & $9.49 \pm 0.45^{\mathrm{a}}$ & $8.92 \pm 0.53^{\mathrm{a}}$ \\
MRS / 24 h & $9.85 \pm 0.54^{\mathrm{a}}$ & $8.70 \pm 0.63^{\mathrm{a}}$ \\
MRS / 48 h & $9.80 \pm 0.30^{\mathrm{a}}$ & $8.22 \pm 0.47^{\mathrm{a}}$ \\
\hline
\end{tabular}

${ }^{*}$ Means \pm standard deviation in the same column followed by different lowercase letters indicate statistically significant differences at $\mathrm{p} \leq$ 0.05 between incubation temperatures and type of culture medium $(n=3)$. Source: Authors.

\subsection{Effect of the drying technology}

The populations of L. casei and L. acidophilus in the probiotic powders before and after the oven-drying and freezedrying processes are presented in Table 6. Microbial viability values of L. casei were $9.46 \mathrm{log}$ cfu/mL before the drying process, $7.64 \log \mathrm{cfu} / \mathrm{mL}$ after the freeze-drying and $9.98 \log \mathrm{cfu} / \mathrm{mL}$ after the oven-drying. For L. acidophilus it was observed $8.95 \log \mathrm{cfu} / \mathrm{mL}$ before the drying process, $4.00 \log \mathrm{cfu} / \mathrm{mL}$ after the freeze-drying and $8.22 \log \mathrm{cfu} / \mathrm{mL}$ after the oven-drying. It is suggested that the final probiotic product should contain at least $10^{6}-10^{7} \mathrm{cfu} / \mathrm{mL}$ of the probiotic bacteria (Flach, et al., 2017). Therefore, the freeze-drying of L. acidophilus was not a suitable metholody to produce probiotic powders, as only 4.00 $\log \mathrm{cfu} / \mathrm{mL}$ of the probiotic culture could be obtained.

It was verified that when the oven-drying method was used for the two microorganisms evaluated, there was no significant reduction of the populations $(\mathrm{p}>0.0 .5)$, when comparing the products before and after the drying methodology. For the freeze-drying process there was a significant decrease $(\mathrm{p}<0.05)$ in the population of both probiotic cultures. The reductions observed were of approximately $2 \log$ cycles for L. casei and more than $4 \log$ cycles for L. acidophilus.

The most popular drying methodology for probiotic preservation is freeze-drying, due to its reliability in the cell viability and long storage time. However, it is one of the most expensive drying methodologies, as it operates at extremely low temperatures and vacuum condition over a long drying time (Tan, et al., 2018). The lower probiotic survival to the freezedrying process could be related to the intra- and extracellular damage due to ice crystal formation (Flach, et al., 2017).

This study proved that the oven-drying is a promising technique, as it was operated at intermediate temperatures (40 ${ }^{\circ} \mathrm{C}$ ) and resulted in higher probiotic counts (L. casei and L. acidophilus). Therefore, the low temperature was suitable, whith absence of the harmful actions associated to the high temperature, such as damage in citoplasmatic probiotic membrane, protein denaturation and activity loss of DNA and ribosomes (Alves et al., 2017). Due to the simpler mechanism, oven-drying generally has low processing costs and the combined capital and operational costs is only about $25.2 \%$ when compared to freeze-drying (Tan, et al., 2018). 
Table 6. Probiotic viability before and after the drying processing.

\begin{tabular}{ccc}
\hline Incubation parameters & $\begin{array}{c}\text { L. casei } \\
(\operatorname{log~cfu} / \mathrm{mL})\end{array}$ & $\begin{array}{c}\text { L. acidophilus } \\
(\log \mathrm{cfu} / \mathrm{mL})\end{array}$ \\
\hline Before & $9.46 \pm 0.53^{\mathrm{a}}$ & $8.95 \pm 0.47^{\mathrm{a}}$ \\
Freeze-drying & $7.64 \pm 0.39^{\mathrm{b}}$ & $4.00 \pm 0.36^{\mathrm{b}}$ \\
Oven-drying & $9.98 \pm 0.48^{\mathrm{a}}$ & $8.22 \pm 0.51^{\mathrm{a}}$ \\
\hline
\end{tabular}

*Means \pm standard deviation in the same column followed by different lowercase letters indicate statistically significant differences at $\mathrm{p} \leq$ 0.05 between drying method for the same probiotic culture $(n=3)$. Source: Authors.

\section{Conclusion}

This study proved that cheese whey can be a suitable growth promoter for both probiotic cultures and oven-drying could be the drying method, which can decrease the production costs. For L. casei, the best growth condition would be with the addition of cheese whey $(16 \% \mathrm{w} / \mathrm{v})$ plus ammonium sulfate $(2.5 \% \mathrm{w} / \mathrm{v})$, incubation at $35{ }^{\circ} \mathrm{C}$ for $24 \mathrm{~h}$ and oven-drying at $40{ }^{\circ} \mathrm{C}$ for $24 \mathrm{~h}$. For L. acidophilus, the best growth condition would be with the addition of cheese whey $(12 \% \mathrm{w} / \mathrm{v})$ plus yeast extract (7\% w/v), incubation at $39{ }^{\circ} \mathrm{C}$ for $24 \mathrm{~h}$ and oven-drying at $40{ }^{\circ} \mathrm{C}$ for $24 \mathrm{~h}$. Hence this study presents a simplified and costeffective process that has the potential to be employed in the industrial production of probiotic powder. The probiotic powder developed would have several purposes, from the industrial point of view it could be used in flavored milk, dairy dessert or chocolate powder. Furthermore, it could be used directly by the consumers, which could broaden the range of food applications and allow the probiotic consumption by lactose intolerants and people with galactosemia or dairy allergy.

\section{References}

Alves, N. N., Sancho, S. O., Silva, A. R. A. , Desobry, S., Costa, J. M. C. \& Rodrigues, S. (2017). Spouted bed as an efficient processing for probiotic orange juice drying. Food Research International, 101, 54-60.

Ayodeji, B. D., Piccirillo, C., Ferraro, V., Moreira, P. R., Obadina, A. O., Sanni, L. O. \& Pintado, M. M. (2017). Screening and molecular identification of lactic acid bacteria from gari and fufu and gari effluents. Annals of Microbiology, 67(1), 123-133.

Bevilacqua, A., Petruzzi, L., Speranza, B., Campaniello, D., Sinigaglia, M. \& Corbo, M. R. (2018). Changes of the cell surface hydrophobicity of Lactobacillus acidophilus La-5 in response to $\mathrm{pH}$, temperature and inulin. International Journal of Food Science \& Technology, 53(5), $1262-1268$.

Flach, J., van der Waal, M. B., van der Nieuwboer, M., Claassen, E. \& Larsen, O. F. (2017). The underexposed role of food matrices in probiotic products: Reviewing the relationship between carrier matrices and product parameters. Critical Reviews in Food Science and Nutrition, 58(15):2570-2584..

Guergoletto, K. B., Magnani, M., Martin, J. S., Andrade, C. G. T. J. \& Garcia, S. (2010). Survival of Lactobacillus casei (LC-1) adhered to prebiotic vegetal fibers. Innovative Food Science \& Emerging Technologies, 11(2), 415-421.

Hill, C., Guarner, F., Reid, G., Gibson, G. R., Merenstein, D. J., Pot, B., Morelli, L., Canani, R. B., Flint, H. J., Salminen, S., Calder, P. C. \& Sanders, M. E. (2014). Expert consensus document: The International Scientific Association for Probiotics and Prebiotics consensus statement on the scope and appropriate use of the term probiotic. Nature Reviews Gastroenterology and Hepatology, 11(8), 506-514.

Hu, P. L., Yuan, Y. H., Yue, T. L. \& Guo, C. F. (2018). A new method for the in vitro determination of the bile tolerance of potentially probiotic lactobacilli. Applied Microbiology and Biotechnology, 102(4), 1903-1910.

Kareb, O. \& Aïder, M. (2018). Whey and Its Derivatives for Probiotics, Prebiotics, Synbiotics, and Functional Foods: a Critical Review. Probiotics and Antimicrobial Proteins, 11(2), 348-369.

Librán, C. M., Castro, S. \& Lagaron, J. M. (2017). Encapsulation by electrospray coating atomization of probiotic strains. Innovative Food Science \& Emerging Technologies, 39, 216-222.

Lv, X., Liu, G., Sun, X., Chen, H., Sun, J. \& Feng, Z. (2017). Nutrient consumption patterns of Lactobacillus acidophilus KLDS 1.0738 in controlled pH batch fermentations. Journal of Dairy Science, 100(7), 5188-5194.

Manzoor, A., Qazi, J. I., ul Haq, I., Mukhtar, H. \& Rasool, A. (2017). Significantly enhanced biomass production of a novel bio-therapeutic strain Lactobacillus plantarum (AS-14) by developing low cost media cultivation strategy. Journal of Biological Engineering, $11(1), 17$.

Pato, U., Yusuf, Y., Rossi, E., Yunaira, R. \& Githasari, T. (2017). Quality of Probiotic Fermented Milk using Lactobacillus casei subsp. casei R-68 as a Starter with the Variation of Skim Milk and Sucrose. International Journal of Agricultural Technology, 13(1), 37-46.

Sabo, S. S., Pérez-Rodríguez, N., Domínguez, J.M. \& Oliveira, R.P.S. (2017). Inhibitory substances production by Lactobacillus plantarum ST16Pa cultured in hydrolyzed cheese whey supplemented with soybean flour and their antimicrobial efficiency as biopreservatives on fresh chicken meat. Food Research International, 99(1), 762-769. 
Research, Society and Development, v. 10, n. 16, e420101623796, 2021

(CC BY 4.0) | ISSN 2525-3409 | DOI: http://dx.doi.org/10.33448/rsd-v10i16.23796

Shu, G., Wang, Z., Chen, L., Wan, H. \& Chen, H. (2018). Characterization of freeze-dried Lactobacillus acidophilus in goat milk powder and tablet: Optimization of the composite cryoprotectants and evaluation of storage stability at different temperature. Food Science and Technology, 90(1), 70-76.

Sigma-Aldrich (2021). https://www.sigmaaldrich.com.

Tabassum., A., Shiby, V. K. \& Pandey, M. C. (2017). Quality aspects and Storage evaluation of Freeze Dried Probiotic Pineapple Lassi Powder. Defence Life Science Journal, 2(2), 186-192.

Tan, D. T., Poh, P. E. \& Chin, S. K. (2018). Microorganism preservation by convective air-drying-A review. Drying Technology, 36(7), 764-779.

Thakur, A., Panesar, P. S. \& Saini, M. S. (2018). Parametric Optimization of Lactic Acid Production by Immobilized Lactobacillus casei Using Box-Behnken Design. Periodica Polytechnica Chemical Engineering, 62(3), 274-285.

Zotta, T., Tabanelli, G., Montanari, C., Ianniello, R. G., Parente, E., Gardini, F. \& Ricciardi, A. (2017). Tween 80 and respiratory growth affect metabolite production and membrane fatty acids in Lactobacillus casei N87. Journal of applied microbiology, 122(3), 759-769. 